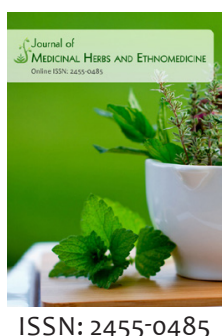

Received: April 16, 2020 Revised: May 01, 2020 Accepted: May 02, 2020 Published: May 06, 2020

*Corresponding Author: Vijender Kumar, Email: vijenderpareek24@ yahoo.com

\section{In-vitro anti-inflammatory and anti-arthritic activities of ethyl acetate extract of Skimmia anquetilia leaves}

\author{
Poonam Verma', Baljinder Singh', Amarjit Kaur², Vijender Kumar ${ }^{3 *}$ \\ 'Lala Lajpat Rai College of Pharmacy, Near P.S.Sadar, Moga-142001, Punjab, India, '2Department of Pharmaceutical \\ Chemistry, ISF College of Pharmacy, Moga-142001, Punjab, India, ${ }^{3}$ University Institute of Pharmaceutical Sciences \& \\ Research, BFUHS, Faridkot-151203, Punjab, India
}

\begin{abstract}
Current investigations were carried out for the validation of in-vitro anti-inflammatory and anti-arthritic property of leaves of Skimmia anquetilia using red blood cells membrane stabilization and protein denaturation methods respectively. Defatted ethylacetate extracts at different concentration levels (50, 100, 200 and $400 \mathrm{mg} / \mathrm{ml}$ ) were used in these studies. Dose dependent inhibition of protein denaturation was found $92.41 \%$ at $400 \mathrm{mg} / \mathrm{ml}$ of extracts and $96.21 \%$ at $100 \mathrm{mg} / \mathrm{ml}$ of acetyl salicylic acid as standard in antiarthritic study. Similarly, in membrane stabilization methods, maximum effect found $90.70 \%$ at $400 \mathrm{mg} / \mathrm{ml}$ of extracts and $94.88 \%$ at $100 \mathrm{mg} / \mathrm{ml}$ of diclofenac sodium as standard for anti-inflammatory evaluation. The results concluded that, ethyl acetate extract of $S$. anquetilia leaves has shown significant $\left({ }^{*} \mathrm{P}<0.05\right)$ anti-inflammatory and anti-arthritic effects.
\end{abstract}

KEYWORDS: Skimmia anquetilia, In-vitro anti-inflammatory, Anti-arthritic activity, Membrane stabilization assay, Protein denaturation method

\section{INTRODUCTION}

Inflammation is a self defense mechanism of the body to protect against reaction to infection, irritation or allegens or any other harmful irritation. It is a part of the host defense mechanisms. It is known to be involved in the inflammatory reactions such as release of histamine, bradykinin, prostaglandins, extravasations, cell migration, tissue breakdown and repair which are aimed at host defense and usually activated in most disease condition. The critical role of inappropriate inflammation is becoming accepted in many diseases that affect man, including cardiovascular diseases, inflammatory and autoimmune disorders, neurodegenerative conditions, infection and cancer[1]. Stabilization of lysosomal membrane is important in inflammatory response by inhibiting the release of lysosomal constituents of activated neutrophil for example bactericidal enzymes and proteases, which cause tissue inflammation and damage upon extra cellular release or by stabilizing the lysosomal membrane[2]. HRBC or erythrocyte membrane is analogous to the lysosomal membrane and its stabilization implies that the extract may as well stabilize lysosomal membranes. Stabilization of human red blood cell membrane by hypotonicity induced membrane lysis can be taken as an in-vitro measure of anti-inflammatory activity of the untapped drugs or plant extracts. Skimmia anquetilia is an aromatic gregarious shrub belonging to family Rutaceae. It is mostly found in Western part of Himalayas and Kashmir in India. Traditionally, the leaf infusion of $S$. anquetilia is taken for treatment of headache, freshness and general fever $[1,3]$. The leaves of $S$. anquetilia are aromatic and known to contain linalool, geraniol, pinene, scopoletin, skimmianine, umbelliferone[3]. The present investigations are scientifically validated in vitro anti- inflammatory effects using human red blood cell membrane stabilization and anti-arthritic activity by protein denaturation assay methods.

\section{MATERIALS AND METHODS}

\section{Plant Material}

Skimmia anquetilia leaves were collected from Gulmarg area of Kashmir (J\&K, India). The defatted ethyl acetate extracts of $S$. anquetilia leaves (EESA) were prepared from air dried leaves.

\section{In vitro Anti-inflammatory Activity}

\section{Red blood cell membrane stabilization method}

Human red blood cell (HRBC) membrane stabilization method was performed as described by Kumar et al[4]. The blood was

Copyright: $\odot$ The authors. This article is open access and licensed under the terms of the Creative Commons Attribution License (http://creativecommons.org/licenses/by/4.0/) which permits unrestricted, use, distribution and reproduction in any medium, or format for any purpose, even commercially provided the work is properly cited. Attribution - You must give appropriate credit, provide a link to the license, and indicate if changes were made. 
collected from healthy human volunteer who had not taken any NSAIDS for 2 weeks prior to the experiment and mixed with equal volume of Alsever solution (2\% dextrose, $0.8 \%$ sodium citrate, $0.5 \%$ citric acid and $0.42 \% \mathrm{NaCl}$ ) and centrifuged at $3000 \mathrm{rpm}$. The packed cells were washed with isosaline and a $10 \%$ suspension was made.

Ehyl acetate extracts of S. anquetilia leaves was prepared and evaluated at different levels 100, 200 and $400 \mathrm{mg} / \mathrm{mL}$ ) using distilled water and to each concentration $1 \mathrm{ml}$ of phosphate buffer, $2 \mathrm{ml}$ hyposaline and $0.5 \mathrm{ml}$ of HRBC suspension were added. It was incubated at $37^{\circ} \mathrm{C}$ for $30 \mathrm{~min}$ and centrifuged at $3000 \mathrm{rpm}$ for $20 \mathrm{~min}$. The hemoglobin content of the supernatant solution was estimated with UV spectrophotometer at $560 \mathrm{~nm}$. Diclofenac $(50 \mathrm{mg} / \mathrm{mL})$ was used as reference standard and a control was prepared by omitting the extracts. The experiment was performed in triplicate. The percentage of HRBC membrane stabilization or protection was calculated by using the formula mentioned below:-

$$
\text { Percent inhibition }=\frac{\text { Abs. of Control }- \text { Abs. of treated }}{\text { Abs. of Control }} \times 100
$$

\section{In-vitro Anti-arthritic Activity}

\section{Inhibition of protein denaturation method}

Inhibition of protein denaturation method was performed as described by Kumari et al[5]. The suspension test mixture $(2.5 \mathrm{ml})$ consisted of $2.2 \mathrm{ml}$ bovine serum albumin $(5 \%$ aqueous solution) and $0.3 \mathrm{ml}$ of $S$. anquetilia leaves extract at different concentration levels 100, 200 and $400 \mathrm{mg} / \mathrm{mL}$. The samples were incubated at $37^{\circ} \mathrm{C}$ for $30 \mathrm{~min}$. After cooling the samples, $7.5 \mathrm{ml}$ phosphate buffer saline ( $\mathrm{pH} 6.3$ ) was added to each tube. Turbidity was measured UV spectrophotometer at $660 \mathrm{~nm}$ for control test $0.3 \mathrm{ml}$ distilled water was added instead of extracts while product control test lacked bovine serum albumin. The percentage inhibition of protein denaturation was calculated as follows.

Percent inhibition $=\frac{\text { Abs. of Control }- \text { Abs. of treated }}{\text { Abs. of Control }}$ X100

The control represents 100\% protein denaturation. The results were compared with acetyl salicylic acid $(50 \mathrm{mg} / \mathrm{ml})$ treated samples.

\section{RESULTS}

Human red blood cell membrane stabilization method reflects the effect of drugs on cellular membrane i.e. red blood cell. Since HRBC membrane are similar to lysomal membrane components $[5,6]$. The prevention of hypotoxicity induces HRBC membrane lysis is taken as a measure of antiinflammatory activity of drugs. The ethyl acetate extract of $S$. anquetilia showed significant anti-inflammatory activity at the concentration of $400 \mathrm{mg} / \mathrm{ml}$ which is comparable to the standard drug diclofenac sodium $(100 \mathrm{mg} / \mathrm{ml})$. In-vitro anti-inflammatory activity of the extracts showed concentration dependent activity.
Table 1: Effect of ethyl acetate extract of $S$. anquetilia leaves (EESA) on HRBC membrane stabilization anti-inflammatory activity

\begin{tabular}{lcc}
\hline Extracts/ Drug & Concentration $(\mathrm{mg} / \mathrm{ml})$ & Percentage inhibitions \\
\hline Control & ---- & --- \\
EESA $^{*}$ & 50 & $22.18 \pm 0.12$ \\
& 100 & $36.11 \pm 1.10^{\mathrm{b}}$ \\
& 200 & $74.31 \pm 2.35$ \\
& 400 & $90.70 \pm 3.12^{\mathrm{a}}$ \\
Diclofenac sodium & 100 & $94.88 \pm 2.52^{\mathrm{a}}$ \\
\hline
\end{tabular}

*EESA- Ethyl acetate extracts of $S$. anquetilia leaves. Data's statistical significance found as: ${ }^{\text {a }} \mathrm{P}<0.01,{ }^{\mathrm{b}} \mathrm{P}<0.05$

Table 2: Effect of ethyl acetate extract of $S$. anquetilia leaves (EESA) on Protein denaturation method for anti-arthritic activity

\begin{tabular}{lcc}
\hline Extracts/ Drug & Concentration $(\mathrm{mg} / \mathrm{ml})$ & Percentage inhibitions \\
\hline Control & --- & --- \\
& 50 & $28.12 \pm 0.18^{\mathrm{b}}$ \\
EESA * & 100 & $44.35 \pm 2.33$ \\
& 200 & $72.14 \pm 3.21^{\mathrm{a}}$ \\
& 400 & $92.41 \pm 2.4^{\mathrm{b}}$ \\
Acetyl salicylic acid & 100 & $96.21 \pm 3.4^{\mathrm{a}}$ \\
*EESA- Ethyl acetate extracts of $S$. anquetilia leaves. Data's statistical &
\end{tabular}

Table 1. Effect of EESA on HRBC Membrane Stabilization

Human red blood cell membrane stabilization results are tabulated in Table 1. The results of 50, 100, 200 and $400 \mathrm{mg} / \mathrm{ml}$ of EESA showed concentration dependent activity respectively i.e. $22.18 \%, 36.11 \%, 74.31 \%$ and $90.70 \%$. Among all the concentration, EESA $100 \mathrm{mg}$ and $400 \mathrm{mg}$ were found statistically significant $\left({ }^{* a} \mathrm{P}<0.05\right)$. All the results of test drugs were compared with control and standard drug diclofenac sodium which showed $94.88 \%$ protection (Table 1).

\section{Table 2. Effect of EESA on Protein Denaturation Method}

The production of auto antigens in certain arthritic diseases may be due to denaturation of protein and membrane lysis action. Denaturation of protein causes the production of auto antigens in conditions such as rheumatic arthritis, cancer and diabetes which are conditions of inflammation [7]. Hence, by inhibition of protein denaturation, inflammatory activity can be inhibited. The results of 50, 100, 200 and $400 \mathrm{mg} / \mathrm{ml}$ of EESA showed 28.12\%, 44.35\%, $72.14 \%$ and $92.41 \%$ activit and among all the concentration, EESA $50 \mathrm{mg}$ and $400 \mathrm{mg}$ were found statistically significant $\left({ }^{* \mathrm{~b}} \mathrm{P}<0.05\right)$. The maximum \% inhibition of protein denaturation was observed $92.14 \%$ at $400 \mathrm{mg} / \mathrm{ml}$ and with standard drug acetyl salicylic acid shows $96.21 \%$ at $100 \mathrm{mg} / \mathrm{ml}$, results are shown in Table 2 .

\section{CONCLUSION}

The present investigations are scientifically validated in vitro using human red blood cell membrane stabilization and protein denaturation assay methods, it supported to traditional claim as 
anti- inflammatory and anti-arthritic activity respectively. It can be concluded that the ethyl acetate extract of leaves of Skimmia anquetilia can be further used for in-vivo activities related to anti- inflammatory and anti-arthritic activity.

\section{CONFLICTS OF INTEREST}

No potential conflicts of interest were disclosed.

\section{REFERENCES}

1. Kumar V., Bhat Z.A., Kumar D., Khan N.A., Chashoo I.A. Evaluation of anti-inflammatory potential of leaf extracts of Skimmia anquetilia. Asian Pac J Trop Biomed, 2012, 2(8): 627-630.

2. Vadivu R, Lakshmi KS. In vitro and in vivo anti inflammatory activity of leaves of Symplocos cochinchinensis (Lour) Moore ssp Laurina. Bangladesh J Pharmacol, 2008,3: 121-124.

3. Kunwar RM, Shrestha KP, Bussmann RW. Traditional herbal medicine in Far-west Nepal: a pharmacological appraisal. J Ethnobiol \& Ethnomed, 2010, 6: 35. doi:10.1186/1746-4269-6-35.

4. Kumar V, Bhat ZA, Kumar D, Bohra P, Sheela S. In-vitro antiinflammatory activity of leaf extracts of Basella alba linn. var. alba. Int. J. Drug. Dev. \& Res., 2011, 3(2): 124-127.

5. Kumari C.S., Yasmin N., Hussain M. R. and Babuselvam M. In vitro anti- inflammatory and anti-arthritic property of Rhizopora mucronata leaves. International Journal of Pharma Sciences and Research., 2015, 6:.3:482-485.

6. Babuselvam M, Ravikumar S, Mohamed Farook KA, Abideen S, Peer Mohamed $\mathrm{M}$ and Uthiraselvam M. Evaluation of anti-inflammatory and analgesic effects on the extracts of different parts of Excoecaria agallocha L. J. Appl Pharma Sci, 2012, 2 (9): 108-12.

7. Mizushima Y., and Kobayashi, M. Interaction of anti-inflammatory drugs with serum proteins, especially with some biologically active proteins, Journal of Pharmacy and Pharmacology, 1968, 20(3), 169-173. 